\title{
Bioremediation of Swine Wastewater and Biofuel Potential by using Chlorella vulgaris, Chlamydomonas reinhardtii, and Chlamydomonas debaryana
}

\author{
Rifat Hasan ${ }^{1}$, Bo Zhang ${ }^{2,3 *}$, Lijun Wang ${ }^{2}$ and Abolghasem Shahbazi
}

${ }^{1}$ Chemical, Biological and Bioengineering Department, North Carolina A\&T State University, Greensboro North Carolina, USA

${ }^{2}$ Department of Natural Resources and Environmental Design, North Carolina A\&T State University Greensboro, North Carolina, USA

${ }^{3}$ School of Chemical Engineering and Pharmacy, Wuhan Institute of Technology, Hubei, China

\begin{abstract}
Four commercial microalgae strains of Chlorella vulgaris, Chlamydomonas reinhardtii, Scenedesmus dimorphus and Neochloris oleoabundans, and a local strain of Chlamydomonas debaryana were studied in this research. It's found that $S$. dimorphus and $N$. oleoabundans were unable to grow on the swine wastewater. The optimal culture conditions for $C$. vulgaris and $C$. reinhardtii were found to be $\left(600 \mu \mathrm{mol} \mathrm{m}^{-2} \mathrm{~s}^{-1}\right.$ and $\left.25^{\circ} \mathrm{C}\right)$ and $\left(300 \mu \mathrm{mol} \mathrm{m}^{-2} \mathrm{~s}^{-1}\right.$ and $20^{\circ} \mathrm{C}$ ), respectively. The growth kinetics was determined using Optical Density (OD) method and flow cytometry. Under the optimal culture conditions, the highest specific growth rates were found to be 1.336 day $^{-1}$ and 1.286 day $^{-1}$ for $C$. vulgaris and $C$. reinhardtii, respectively. The removal efficiency of nutrients from the wastewater is a function of microalgae growth. When comparing a local $C$. debaryana strain with these two commercial strains, the final biomass yields and lipid contents were $1.25 \mathrm{~g} / \mathrm{L}$ and $15.2 \%$ (of the total cell dry weight), $0.86 \mathrm{~g} / \mathrm{L}$ and $19.7 \%$, and $0.73 \mathrm{~g} / \mathrm{L}$ and $21.7 \%$ for $C$. vulgaris, C. debaryana and C. reinhardtii, respectively. In addition, the lipids from these microalgal strains contain a variety of fatty acids, which are suitable for the biofuel production.
\end{abstract}

Keywords: Microalgae; Bioremediation; Swine wastewater; Growth rate; Lipid

\section{Introduction}

Nowadays, it is truism to recognize that the pollution problem is a major concern of the society. Environmental laws are given general applicability and their enforcement has been gradually stricter [1]. The strategic importance of fresh water and air is universally recognized more than ever before. Issues concerning sustainable water management and air pollution can be found almost in every agenda all over the world. There are few things invented which can be used to mitigate both water and air pollution. Microalgal technology is one of them which can be used to reduce these crises as it ensures sustainable management of both air and water.

Microalgae are a diverse group of prokaryotic and eukaryotic photosynthetic microorganisms, typically found in freshwater and marine systems [2]. Algae are essential to global carbon, nitrogen and sulfur cycling. Approximately $45 \%$ of photosynthetic carbon assimilation is achieved by algae [3]. In addition, microalgae are considered as a promising feedstock for biofuel production. The oil yield of some algal stains is 1,000-4,000 gallons of oil/acre/yr whereas soybeans and other oil crops can generate 48 gallons of oil/acre/yr approximately. As an energy crop, microalgae do not compete with grain crops for limited arable lands because they may grow in water.

Bioremediation of wastewater using algal strains such as Chlorella and Dunaliella, spans over 75 years [3]. Algae bioremediation was applied for a range of purposes, some of which are used for the removal of coliform bacteria, reduction of Chemical Oxygen Demand and Biochemical Oxygen Demand (COD, BOD), removal of $\mathrm{N}$ and/or P, and also for the removal of heavy metals [1]. A number of microalgal strains including Ourococcus multisporus, Nitzschia cf. pusilla, Chlamydomonas mexicana, Scenedesmus obliquus, Chlorella vulgaris, Chlorella zofingiensis, and Micractinium reisseri had been used to treat municipal wastewater treatment effluents, livestock wastewater, agroindustrial wastewater and industrial wastewater [4-6]. Growing algae requires the consideration of three primary nutrients: carbon, nitrogen, and phosphorus. Micronutrients required in traceable amounts include silica, calcium, magnesium, potassium, iron, manganese, sulfur, zinc, copper, and cobalt, although the supply of these essential micronutrients rarely limits algal growth when wastewater is used.

Therefore, the ultimate objective of this research is to optimize the growth conditions and determine growth kinetics of selected microalgal strains to assimilate nutrients in wastewater for swine wastewater treatment and bioenergy production. The growth characteristics and composition of microalgae are known to significantly depend on the cultivation conditions, such as light intensity, photoperiod, temperature, $\mathrm{CO}_{2}$ flow rate, nutrient composition, etc. [7]. In order to optimize the growth and lipid content of microalgae, it is required to combine all growth parameters in a systemic way so that the efficiency of an algal growth system can be maximized. In this study, the effects of cultivation temperature, light intensity, and nutrient removal on microalgae growth were observed.

\section{Materials and Method}

\section{Microalgae strains and pre-culture conditions}

Four microalgae strains of Chlorella vulgaris (UTEX 2714),

*Corresponding author: Bo Zhang, Department of Natural Resources and Environmental Design, North Carolina A\&T State University, 1601 East Market Street, Greensboro, NC 27411, USA, Tel: 336-334-7787; Fax: 336-334-7270; E-mail: bzhang@ncat.edu

Received May 16, 2014; Accepted June 26, 2014; Published July 03, 2014

Citation: Hasan R, Zhang B, Wang L, Shahbazi A (2014) Bioremediation of Swine Wastewater and Biofuel Potential by using Chlorella vulgaris, Chlamydomonas reinhardtii, and Chlamydomonas debaryana. J Pet Environ Biotechnol 5: 175. doi:10.4172/2157-7463.1000175

Copyright: (C) 2014 Hasan R, et al. This is an open-access article distributed under the terms of the Creative Commons Attribution License, which permits unrestricted use, distribution, and reproduction in any medium, provided the original author and source are credited. 
Chlamydomonas reinhardtii (UTEX 90), Scenedesmus dimorphus (UTEX 1237) and Neochloris oleoabundans (UTEX 1185) were obtained from the Culture Collection of Algae at the University of Texas at Austin (UTEX). Chlamydomonas debaryana AT24 was isolated from the lagoon at the farm of the North Carolina A\&T State University (NC A\&T). C. vulgaris, S. dimorphus, and C. debaryana were preserved in the Proteose medium. C. reinhardtii and N. oleoabundans were preserved in the Soil Extract medium. Proteose medium consists of the following ingredients: $\mathrm{NaNO}_{3}(2.94 \mathrm{mM}), \mathrm{CaCl}_{2} .2 \mathrm{H}_{2} \mathrm{O}(0.17 \mathrm{mM})$, $\mathrm{MgSO}_{4} .7 \mathrm{H}_{2} \mathrm{O}(0.3 \mathrm{mM}), \mathrm{K}_{2} \mathrm{HPO}_{4}(0.43 \mathrm{mM}), \mathrm{KH}_{2} \mathrm{PO}_{4}(1.29 \mathrm{mM})$, $\mathrm{NaCl}(0.43 \mathrm{mM})$, and Proteose Peptone $\left(1 \mathrm{~g} \mathrm{~L}^{-1}\right)$. Soil extract medium consists of the following ingredients: $\mathrm{NaNO}_{3}(2.94 \mathrm{mM}), \mathrm{CaCl}_{2} .2 \mathrm{H}_{2} \mathrm{O}$ (0.17 mM), $\mathrm{MgSO}_{4} .7 \mathrm{H}_{2} \mathrm{O}(0.3 \mathrm{mM}), \mathrm{K}_{2} \mathrm{HPO}_{4}(0.43 \mathrm{mM}), \mathrm{KH}_{2} \mathrm{PO}_{4}(1.29$ $\mathrm{mM}), \mathrm{NaCl}(0.43 \mathrm{mM})$, and soil water $\left(40 \mathrm{ml} \mathrm{L}^{-1}\right)$.

\section{Culture of microalgae with swine wastewater}

Swine wastewater was collected from a swine growing facility at the NC A\&T farm, and used as the substrate to cultivate microalgae. Pretreatment of swine wastewater was carried out by sedimentation and filtration with a Whatman quantitative filter paper $(8 \mu \mathrm{m}$ pore $)$ to remove large, non-soluble particulate solids. After filtration the wastewater was autoclaved for $15 \mathrm{~min}$ at $121^{\circ} \mathrm{C}$.

In order to investigate the effect of environmental factors on microalgae growth, an AlgaeTron Multi-Cultivator MC 1000 photobioreactor (Brno, Czech Republic) was used. It consists of eight $100 \mathrm{ml}$ tubular bioreactors. The temperature of the bioreactors is controlled centrally, and each bioreactor is independently illuminated by an array of white LEDs. Air is bubbled through each tube at the flow rate of $100 \mathrm{ml} / \mathrm{min}$.

The autoclaved wastewater was used accordingly as medium for algal cultivation. Subsequently, $72 \mathrm{ml}$ of swine wastewater and $8 \mathrm{ml}$ of seed microalgae suspension were introduced into each photobioreactor. In all cases, microalgae were cultured in the swine wastewater for 15 days varying light intensity $\left(300,600\right.$ and $\left.900 \mu \mathrm{mol} \mathrm{m}^{-2} \mathrm{~s}^{-1}\right)$ and temperature $\left(20,25\right.$ and $\left.30^{\circ} \mathrm{C}\right)$. The experimental designs are shown in Table 1. All experiments and analyses were performed in triplicate or duplicate.

\section{Nutrients analysis}

After 15-day cultivation, microalgal cells from each photobioreactor were collected and centrifuged at $4000 \times \mathrm{G}$ and $20^{\circ} \mathrm{C}$ for $15 \mathrm{~min}$. Supernatants from the centrifuge were separated to check the nutrient removal from the wastewater. Supernatants were filtered using a 0.45 $\mathrm{mm}$ nylon membrane filter. Then, the filtrates were appropriately diluted and analyzed for COD, ammonia nitrogen and total phosphorus according to the Lamotte Smart 3 colorimeter manual.
Nutrient removal ratio was defined as following:

$$
\text { Re moval ratio }(\%)=\frac{\text { Nutrient content in the wastewater after a } \lg \text { ae cultivation }}{\text { Nutrient content in the original wastewater }} \times 100
$$

\section{Determination of microalgae growth}

Microalgae growth was monitored by measuring the optical density at $680 \mathrm{~nm}$ every other day. A correlation between the optical density of microalgae at $680 \mathrm{~nm}$ and the cell number was determined by using a Guava easyCyte HT 5 Flow cytometer (Billerica, Massachusetts) and Spectrophotometer.

The specific growth rate $\mu$ in the exponential phase of algal growth was calculated by using equation (2) [8]:

$$
\grave{i}=\frac{\ln \left(\mathrm{N}_{2}-\mathrm{N}_{1}\right)}{\mathrm{t}_{2}-\mathrm{t}_{1}}
$$

Where, $\mathrm{N}_{1}$ and $\mathrm{N}_{2}$ are defined as the cell number concentration (cell/ $\mathrm{ml}$ ) at time $\mathrm{t}_{1}$ and $\mathrm{t}_{2}$, respectively. The time required to duplicate the cell number: division rate $(k)$, was calculated according to the equation (3):

$$
\mathrm{k}=\frac{\mathrm{i}}{\ln 2}
$$

\section{Lipid extraction}

A modified Christie method [9] was applied to quantify the amount of total lipid content. Approximately 0.1-0.2 g dried microalgae were weighed into clean screw-top glass tubes and $5 \mathrm{ml}$ of a 2:1 chloroformmethanol (v/v) mixture was added. The tubes were incubated at $65^{\circ} \mathrm{C}$ for $1 \mathrm{hr}$. Then the mixture was centrifuged at $4000 \times \mathrm{G}$ for $10 \mathrm{~min}$, after which the supernatant was collected, and the leftover was re-extracted following the same procedures until the supernatant became colorless. All supernatants were pooled, and then evaporated by blowing nitrogen gas through the tube. The lipid was gravimetrically quantified.

\section{Fatty acid methyl ester (FAME) content analysis}

Extracted algal lipids $(\sim 20 \mathrm{mg})$ were weighed into clean, $20 \mathrm{ml}$ screw-top glass tubes, to which $4 \mathrm{ml}$ fresh solution of a mixture of methanol, concentrated sulfuric acid, and chloroform (1.7:0.3:2.0 $\mathrm{v} / \mathrm{v} / \mathrm{v}$ ) was added. The tubes were closed tightly with Teflon tape to avoid leakage, and then weighed. For transesterification, tubes were placed inside a heating block at temperatures of $90^{\circ} \mathrm{C}$ and heated for $60 \mathrm{~min}$. On completion of the reaction, the tubes were cooled down to room temperature and weighed again to dismiss leaking samples. Then, $1 \mathrm{ml}$ distilled water was added into the mixture, and the mixture was thoroughly vortexed for $1 \mathrm{~min}$. After the formation of two phases, the lower phase containing FAME was transferred to a $1.5 \mathrm{ml} \mathrm{GC}$ vial.

\begin{tabular}{|c|c|c|c|c|c|c|c|c|}
\hline \multirow{2}{*}{$\begin{array}{l}\text { Experimental } \\
\text { design number }\end{array}$} & \multirow{2}{*}{$\begin{array}{c}\text { Temperature } \\
\left({ }^{\circ} \mathrm{C}\right)\end{array}$} & \multirow{2}{*}{ 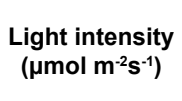 } & \multicolumn{3}{|c|}{ C. vulgaris } & \multicolumn{3}{|c|}{ C. reinhardtii } \\
\hline & & & $\begin{array}{l}\text { Final cell density, } \\
\text { (cell/ml) }\end{array}$ & $\begin{array}{l}\text { Specific growth } \\
\text { rate, } \mu\left(\text { day }^{-1}\right)\end{array}$ & $\begin{array}{c}\text { Division rate, } k \\
\left(\text { day }^{-1}\right)\end{array}$ & $\begin{array}{c}\text { Final cell } \\
\text { density, (cell/mI) }\end{array}$ & $\begin{array}{l}\text { Specific growth } \\
\text { rate, } \mu\left(\text { day }^{-1}\right)\end{array}$ & $\begin{array}{c}\text { Division rate, } \mathbf{k} \\
\left.\text { (day }^{-1}\right)\end{array}$ \\
\hline 1 & \multirow{3}{*}{20} & 300 & $9.5 \times 10^{6}$ & 1.317 & 1.900 & $7.9 \times 10^{6}$ & 1.286 & 1.854 \\
\hline 2 & & 600 & $7.6 \times 10^{6}$ & 1.297 & 1.872 & $7.1 \times 10^{6}$ & 1.271 & 1.834 \\
\hline 3 & & 900 & $6.7 \times 10^{6}$ & 1.287 & 1.856 & $6.9 \times 10^{6}$ & 1.249 & 1.802 \\
\hline 4 & \multirow{3}{*}{25} & 300 & $1.1 \times 10^{7}$ & 1.332 & 1.921 & $7.2 \times 10^{6}$ & 1.272 & 1.836 \\
\hline 5 & & 600 & $1.2 \times 10^{7}$ & 1.336 & 1.928 & $7.3 \times 10^{6}$ & 1.275 & 1.839 \\
\hline 6 & & 900 & $9.2 \times 10^{6}$ & 1.223 & 1.764 & $5.6 \times 10^{6}$ & 1.173 & 1.692 \\
\hline 7 & \multirow{3}{*}{30} & 300 & $9.1 \times 10^{6}$ & 1.214 & 1.752 & $5.9 \times 10^{6}$ & 1.184 & 1.708 \\
\hline 8 & & 600 & $8.9 \times 10^{6}$ & 1.211 & 1.747 & $5.8 \times 10^{6}$ & 1.182 & 1.706 \\
\hline 9 & & 900 & $8.9 \times 10^{6}$ & 1.199 & 1.730 & $5.0 \times 10^{6}$ & 1.143 & 1.649 \\
\hline
\end{tabular}
Samples were stored in the freezer $\left(-20^{\circ} \mathrm{C}\right)$ until GC-MS analysis [10].

Chemical compositions of the liquid products were identified using

Table 1: Experimental design and kinetics parameters for microalgae growth. 
a GC-MS (Agilent 7890A gas chromatography with a HP-5MS capillary column $/ 5975 \mathrm{c}$ mass spectrometer). The GC was programmed at $60^{\circ} \mathrm{C}$ for $4 \mathrm{~min}$ and then increased at $10^{\circ} \mathrm{C} / \mathrm{min}$ to $280^{\circ} \mathrm{C}$, and finally held with an isothermal for $5 \mathrm{~min}$. The injector temperature was $250^{\circ} \mathrm{C}$, and the injection size was $1 \mu \mathrm{l}$. The flow rate of the carrier gas (helium) was $1 \mathrm{ml} / \mathrm{min}$. The ion source temperature was $230^{\circ} \mathrm{C}$ for the mass selective detector. The compounds were identified by comparison with the NIST Mass Spectral Database [11].

\section{Elemental and compositional analysis of microalgae}

A Perkin-Elmer 2400 Series II CHNS/O elemental analyzer (Waltham, Massachusetts) was used to analyze the elemental compositions of microalgal biomass. The protein content of microalgae was determined by Dumas method [12]. The moisture content of the biomass was determined by the method of LAP \#001, which is the Laboratory Analytical Procedures (LAPs) developed by the National Renewable Energy Laboratory $[13,14]$. The ash content of the biomass was determined by the method of LAP \#005 [15].

\section{Statistical analysis}

The statistical significance of the cultivation temperature and light intensity on the algal cell density was assessed using ANOVA F-test. The experimental data measured under each condition were pooled together. The significance test was done for each factor using one-way ANOVA. The null hypothesis is that the population means measured at different levels of the experimental factor are all equal. The alternative is that they are not all equal, or the factor is significant. The statistical significance level cut-off was chosen as $\mathrm{P}=0.05$.

\section{Results}

\section{Microalgae growth}

During the preliminary tests of four commercial microalgae strains, it's found that Scenedesmus dimorphus (UTEX 1237) and Neochloris oleoabundans (UTEX 1185) were unable to grow on the swine wastewater. So Chlorella vulgaris (UTEX 2714) and Chlamydomonas reinhardtii (UTEX 90) were further investigated for the bioremediation ability. Correlations between the optical density of C. vulgaris and C. reinhardtii at $680 \mathrm{~nm}$ and the cell number were pre-determined. These correlations are shown as the equations 5 and 6 , which were used to determine the growth kinetics of both species under different conditions.

\section{The correlation for C. vulgaris is}

Cell number $($ cell $/ \mathrm{ml})=8 \times 10^{6} O D_{680}+425897 \mathrm{R}^{2}=0.9588$

The correlation for $\mathrm{C}$. reinhardtii is

$$
\text { Cell number }(\text { cell } / \mathrm{ml})=7 \times 10^{6} O D_{680}+800979 \mathrm{R}^{2}=0.9591
$$

The kinetics parameters for the growth of C. vulgaris and $C$. reinhardtii under different conditions are summarized in Table 1.

The effect of temperature: The temperature range of $20-30^{\circ} \mathrm{C}$ was chosen, because it is easy to achieve in North Carolina. It was found that the optimal growth temperatures for two strains are different. A cultivation temperature of $25^{\circ} \mathrm{C}$ gave the highest specific growth rates for C. vulgaris. The highest specific growth rates and division rates were found to be $1.336 \mathrm{day}^{-1}$ and 1.928 day $^{-1}$, respectively, which were obtained at $25^{\circ} \mathrm{C}$ and $600 \mu \mathrm{mol} \mathrm{m}^{-2} \mathrm{~s}^{-1}$. At $20^{\circ} \mathrm{C}$ the specific growth rates and division rates obtained were 1.287-1.317 day ${ }^{-1}$ and 1.856-1.9 day ${ }^{-1}$, respectively. The lowest growth rates of 1.199-1.214 day ${ }^{-1}$ were found at $30^{\circ} \mathrm{C}$.
For C. reinhardtii, the highest specific growth rate and division rate were found to be 1.286 day $^{-1}$ and $1.854 \mathrm{day}^{-1}$, respectively, which were obtained at $20^{\circ} \mathrm{C}$ and $300 \mu \mathrm{mol} \mathrm{m}^{-2} \mathrm{~s}^{-1}$. At $25^{\circ} \mathrm{C}$ the specific growth rates and division rates obtained were 1.173-1.272 day $^{-1}$ and 1.692-1.839 day ${ }^{1}$, respectively. The lowest growth rates of 1.141-1.184 day ${ }^{-1}$ were found at $30^{\circ} \mathrm{C}$ and $25^{\circ} \mathrm{C} / 900 \mu \mathrm{mol} \mathrm{m}^{-2} \mathrm{~s}^{-1}$.

The effect of light intensity: The reason for the selection of light intensities of $300-900 \mu \mathrm{mol} \mathrm{m} \mathrm{m}^{-2} \mathrm{~s}^{-1}$ is the same as the temperature selection. Moreover, the light intensities of $600 \mu \mathrm{mol} \mathrm{m}^{-2} \mathrm{~s}^{-1}$ and $900 \mu \mathrm{mol} \mathrm{m} \mathrm{s}^{-1}$ were used to study the effect of photoinhibition on microalgae growth.
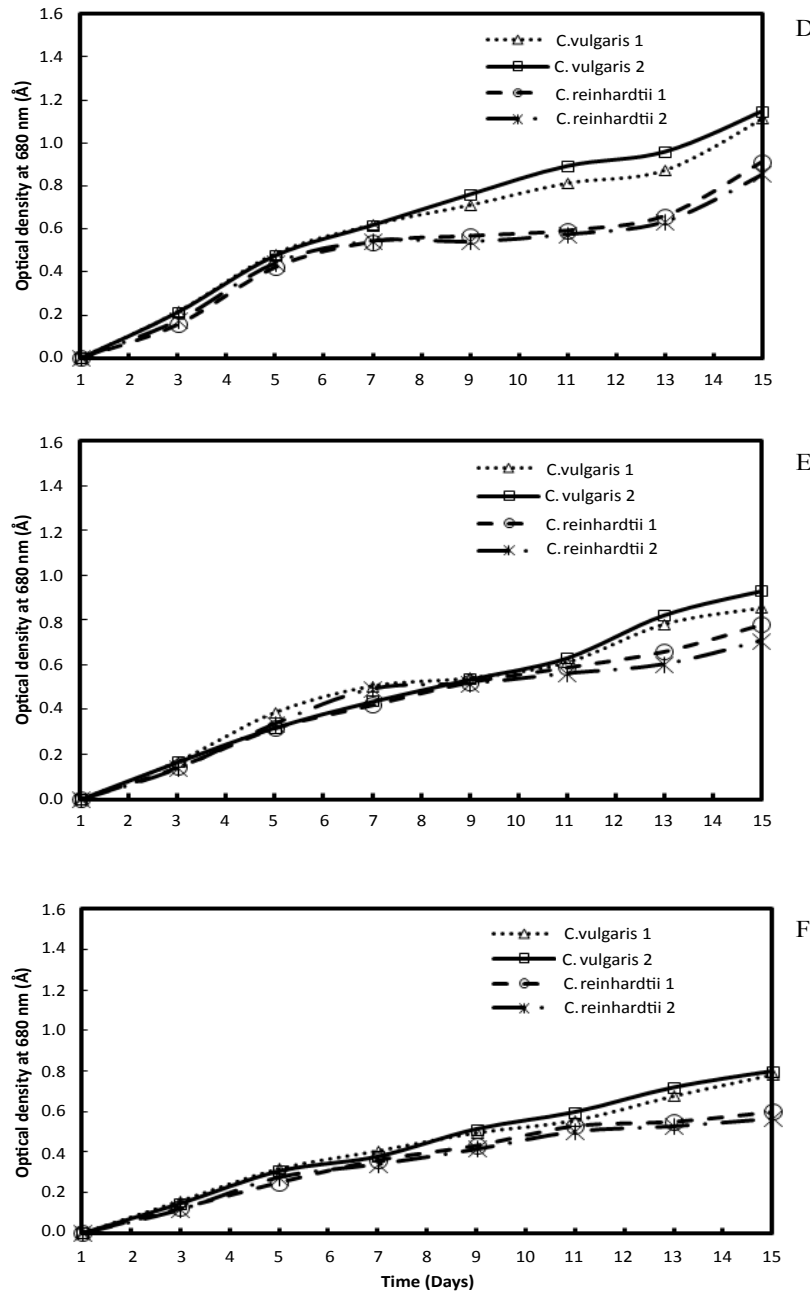

Figure 1: Growth curves of C. vulgaris and C. reinhardtii grown at $20^{\circ} \mathrm{C}$ and a) $300 \mu \mathrm{mol} \mathrm{m}^{-2} \mathrm{~s}^{-1}$, b) $600 \mu \mathrm{mol} \mathrm{m} \mathrm{m}^{-2} \mathrm{~s}^{-1}$, and c) $900 \mu \mathrm{mol} \mathrm{m}^{-2} \mathrm{~s}^{-1}$

\begin{tabular}{|c|c|c|c|}
\hline Nutrients & $\begin{array}{c}\text { Original swine } \\
\text { wastewater }\end{array}$ & $\begin{array}{c}\text { Autoclaved } \\
\text { Wastewater }\end{array}$ & $\begin{array}{c}\text { Autoclaved } \\
\text { wastewater bubbled } \\
\text { with air }\end{array}$ \\
\hline COD $(\mathrm{mg} / \mathrm{L})$ & 2140 & 2060 & 1630 \\
\hline Ammonia Nitrogen $(\mathrm{mg} / \mathrm{L})^{\mathrm{a}}$ & 86.6 & 81.5 & 41.2 \\
\hline Total Phosphorous $(\mathrm{mg} / \mathrm{L})$ & 182.7 & 172.6 & 144.6 \\
\hline $\mathrm{pH}$ & 8.37 & 8.75 & 8.13 \\
\hline
\end{tabular}

a: The total nitrate content in the swine wastewater is negligible.

Table 2: Properties and nutrient contents of swine wastewater. 
Figure 1 shows the growth curves of C. vulgaris and C. reinhardtii at $20^{\circ} \mathrm{C}$ under different light intensities. While microalgae were grown under $300 \mu \mathrm{mol} \mathrm{m}^{-2} \mathrm{~s}^{-1}$, the growth curves revealed different patterns for C. vulgaris and C. reinhardtii. The lag phase was short for both species according to the curve patterns in this phase. The difference was seen in the exponential phase after day 5. The cell density of $C$. vulgaris increased more rapidly in this phase than that of C. reinhardtii. After day 13, C. reinhardtii showed a comparatively high growth rate in this experiment. The cell densities reached the maximum value on day 15 for both species, and the curves were still upslope on day 15, indicating that the growth was still in the exponential phase. The experiments were stopped on day 15 for both species.

When the light intensity was increased from $300 \mu \mathrm{mol} \mathrm{m}^{-2} \mathrm{~s}^{-1}$ to 600 or $900 \mu \mathrm{mol} \mathrm{m}^{-2} \mathrm{~s}^{-1}$, the growth patterns in lag phases were quite similar, and $C$. vulgaris had higher growth rate than $C$. reinhardtii. When the microalgae cultivation was conducted at $25^{\circ} \mathrm{C}$ or $30^{\circ} \mathrm{C}$, the growth patterns of these two microalgal strains showed the similar trends.

Both the growth curves (Figure 1) and the specific growth rates (Table 1) show that a higher light intensity led to a significantly reduced growth rate. The lowest growth rates of both species were found at the highest light intensity of $900 \mu \mathrm{mol} \mathrm{m}^{-2} \mathrm{~s}^{-1}$ and $25^{\circ} \mathrm{C}$.

Statistical analysis: The P-values for the cultivation temperature and light intensity were 0.375 and 0.530 , respectively. If a statistical significance level cut-off is chosen as $\mathrm{P}=0.05$, it is concluded that the cultivation temperature was a significant factor, while the light intensity was not significant at a level of $\mathrm{P}<0.05$.

\section{Removal of COD, ammonia nitrogen, and total phosphorus from swine wastewater}

In this study, the autoclaved wastewater was used as medium for algal cultivation. To provide the mass transfer and $\mathrm{CO}_{2}$, air is bubbled through each bioreactor at the flow rate of $100 \mathrm{ml} / \mathrm{min}$ during the 15-day culture. Table 2 summarizes the contents of COD, ammonia nitrogen, and total phosphorus in the swine wastewater before and after autoclave, and after 15-day air bubbling. By bubbling air through the wastewater, almost all nutrient contents were reduced. In order to calculate the nutrient removal rate, the data of the autoclaved wastewater bubbled with air was used as the reference.

The results indicated that the removal efficiency of nutrients is a function of microalgae growth (Table 3). For both microalgal species, the cultivation conditions for the highest growth rates also resulted in the highest nutrient removal efficiencies. The highest removal efficiencies of ammonia nitrogen, COD, and total phosphorus for $C$. vulgaris were $92.5 \%, 58.9 \%$ and $74.3 \%$, respectively, which was achieved at the temperature of $25^{\circ} \mathrm{C}$ and light intensity of $600 \mu \mathrm{mol} \mathrm{m}^{-2} \mathrm{~s}^{-1}$. For $C$. reinhardtii, the highest removal efficiencies of ammonia nitrogen, COD, and total phosphorus were $89.2 \%, 46.0 \%$ and $48.8 \%$, respectively, which was achieved at the temperature of $20^{\circ} \mathrm{C}$ and light intensity of $300 \mu$ mol m $\mathrm{m}^{-2}$. C. vulgaris often had higher growth rate and removed more nutrients than $C$. reinhardtii under the same cultivation conditions.

\section{Comparison of Chlamydomonas debaryana with C. vulgaris and $C$. reinhardtii}

C. debaryana AT24 is a North Carolina native green microalgal species (unpublished data), which served as a benchmark for the bioremediation ability of the native algal strains. Three strains were cultivated at $25^{\circ} \mathrm{C}$ and light intensity of $300 \mu \mathrm{mol} \mathrm{m}^{-2} \mathrm{~s}^{-1}$. The results of elemental and composition analysis are listed in Table 4 . The protein contents in all microalgal species are significantly high, representing $60-72 \%$ of total dry weight. The ash contents are between $7.9-11.3 \%$ of total dry weight. The final biomass yields were $1.25 \mathrm{~g} / \mathrm{L}, 0.86 \mathrm{~g} / \mathrm{L}$ and $0.73 \mathrm{~g} / \mathrm{L}$ for C. vulgaris, C. debaryana and C. reinhardtii, respectively. C. debaryana was able to remove $88.1 \%$ ammonia nitrogen, $53.6 \%$ total phosphorus, and around $47 \%$ COD from the swine wastewater. $C$. vulgaris gave the highest removal efficiency among three strains, and $C$. debaryana showed better performance than C. reinhardtii.

\section{Lipid extraction and characterization}

Lipids of microalgae were extracted and characterized according to the methods described in the Materials and Method section. Lipid contents from C. vulgaris, C. reinhardtii and C. debaryana are approximately $15.2 \%, 21.7 \%$, and $19.7 \%$ of the total cell dry weight, respectively.

\begin{tabular}{|c|c|c|c|c|c|c|}
\hline \multirow{2}{*}{ Experimental design number } & \multicolumn{3}{|c|}{ C. vulgaris } & \multicolumn{3}{|c|}{ C. reinhardtii } \\
\hline & Ammonia & COD & Phosphorous & Ammonia & COD & Phosphorous \\
\hline 1 & $91.5 \pm 1.0$ & $53.7 \pm 2.2$ & $61.7 \pm 1.3$ & $89.2 \pm 0.9$ & $46.0 \pm 0.4$ & $48.8 \pm 1.2$ \\
\hline 2 & $88.4 \pm 0.3$ & $46.3 \pm 2.3$ & $55.4 \pm 0.8$ & $86.9 \pm 0.7$ & $37.4 \pm 0.9$ & $39.8 \pm 3.2$ \\
\hline 3 & $83.7 \pm 0.7$ & $43.9 \pm 2.2$ & $49.6 \pm 2.2$ & $81.2 \pm 0.2$ & $31.6 \pm 1.3$ & $23.7 \pm 0.8$ \\
\hline 4 & $90.7 \pm 0.5$ & $55.2 \pm 2.6$ & $67.5 \pm 0.4$ & $84.0 \pm 1.0$ & $41.7 \pm 2.6$ & $44.7 \pm 1.5$ \\
\hline 5 & $92.5 \pm 0.3$ & $58.9 \pm 1.7$ & $74.3 \pm 1.8$ & $89.0 \pm 0.9$ & $40.5 \pm 0.9$ & $46.8 \pm 0.3$ \\
\hline 6 & $89.4 \pm 0.2$ & $54.6 \pm 2.6$ & $61.1 \pm 2.3$ & $85.9 \pm 0.3$ & $35.3 \pm 1.3$ & $32.9 \pm 1.2$ \\
\hline 7 & $87.1 \pm 0.3$ & $50.9 \pm 0.9$ & $60.7 \pm 0.4$ & $83.5 \pm 0.3$ & $44.5 \pm 2.2$ & $44.4 \pm 0.9$ \\
\hline 8 & $86.9 \pm 0.3$ & $47.2 \pm 1.7$ & $57.4 \pm 0.5$ & $84.5 \pm 0.7$ & $40.8 \pm 1.3$ & $45.9 \pm 2.4$ \\
\hline 9 & $86.0 \pm 0.2$ & $47.2 \pm 2.6$ & $53.6 \pm 2.0$ & $80.6 \pm 0.3$ & $29.8 \pm 1.3$ & $29.7 \pm 0.7$ \\
\hline
\end{tabular}

Table 3: Removal ratios (\% of the reference) of ammonia nitrogen, COD, and total phosphorous after 15 days culture. The autoclaved swine wastewater that was bubbled with air for 15 days was used as the reference. The reference contains ammonia nitrogen of $41.2 \mathrm{mg} / \mathrm{L}, \mathrm{COD}$ of $1630 \mathrm{mg} / \mathrm{L}$, and phosphorous of $144.6 \mathrm{mg} / \mathrm{L}$.

\begin{tabular}{|c|c|c|c|}
\hline Composition (\% wt) & C. vulgaris & C. reinhardtii & C. debaryana AT24 \\
\hline C & 45.9 & 51.2 \\
\hline H & 6.4 & 7.9 \\
\hline N & 11.6 & 10.3 & 9.5 \\
\hline S & 1.4 & 1.4 & 10.9 \\
\hline ash & 11.3 & 64.4 \\
\hline
\end{tabular}

Table 4: Elemental and composition analysis of microalgae (Moisture free basis, \% by weight). 
Citation: Hasan R, Zhang B, Wang L, Shahbazi A (2014) Bioremediation of Swine Wastewater and Biofuel Potential by using Chlorella vulgaris, Chlamydomonas reinhardtii, and Chlamydomonas debaryana. J Pet Environ Biotechnol 5: 175. doi:10.4172/2157-7463.1000175

Page 5 of 5

\begin{tabular}{|c|c|c|c|c|c|}
\hline Retention time (min) & Possible Formula & Possible chemical structure & C. vulgaris & C. reinhardtii & C. debaryana АT24 \\
\hline 15.2 & $\mathrm{C}_{13} \mathrm{H}_{26} \mathrm{O}_{2}$ & Dadecanoic acid, methyl ester & - & - & + \\
\hline 17.6 & $\mathrm{C}_{15} \mathrm{H}_{30} \mathrm{O}_{2}$ & Methyl tetradecanoate & - & - & + \\
\hline 18.3 & $\mathrm{C}_{16} \mathrm{H}_{32} \mathrm{O}_{2}$ & Tetradecanoic acid, 12-methyl-methyl ester & - & - & + \\
\hline 19.4 & $\mathrm{C}_{17} \mathrm{H}_{30} \mathrm{O}_{2}$ & 7,10-Hexadecandienoic acid, methyl ester & - & - & + \\
\hline 19.7 & $\mathrm{C}_{17} \mathrm{H}_{34} \mathrm{O}_{2}$ & Hexadecanoic acid, methyl ester & + & + & + \\
\hline 20.3 & $\mathrm{C}_{18} \mathrm{H}_{36} \mathrm{O}_{2}$ & Hexadecanoic acid, 15-methyl-methyl ester & - & - & + \\
\hline 21.3 & $\mathrm{C}_{19} \mathrm{H}_{34} \mathrm{O}_{2}$ & Linoleic acid, methyl ester & + & + & + \\
\hline 21.4 & $\mathrm{C}_{19} \mathrm{H}_{32} \mathrm{O}_{2}$ & Linolenic acid, methyl ester & + & + & + \\
\hline 21.6 & $\mathrm{C}_{19} \mathrm{H}_{38} \mathrm{O}_{2}$ & Octadecanoic acid, methyl ester & + & + & + \\
\hline
\end{tabular}

+: present, -: not detectable

Table 5: GC/MS analysis and chemical identification of microalgal oils.

A GC/MS analysis of microalgal oils is presented in Table 5 . Hexadecanoic Acid (C16) and three C18 fatty acids (Linoleic, Linolenic, and Octadecanoic acid) were found in all three microalgal oils. Moreover, the microalgal oil from C. debaryana also contains C12, C14, C15 and C17 fatty acids.

\section{Discussion}

Microalgal technology may combine bioremediation of swine wastewater and biofuel production in a more effective and sustainable way. However, Swine wastewater contains high doses of nutrients, which limited the growth of all microalgal species tested in this study.

As indicated by the statistical analysis, the effect of the light intensity on the algal cell density was not significant, but different microalgae species response to the light intensity differently. When the light intensity increased from 600 to $900 \mu \mathrm{mol} \mathrm{m}^{-2} \mathrm{~s}^{-1}$, the growth rate of C. reinhardtii decreased much more than that of $C$. vulgaris, which may indicate that $C$. reinhardtii is more sensitive to photoinhibition.

C. debaryana AT24 was isolated from the lagoon at a NC A\&T's farm. As a native green microalgal species, $C$. debaryana may have a competitive advantage under the local geographical, climatic and ecological conditions. Application of native microalgal species will also reduce the risk of invasive algae species. In addition, a variety of fatty acids was detected in the microalgal oil from C. debaryana. These medium-chain-length fatty acids are good sources for the production of bio-jet fuel.

\section{Conclusion}

This study describes a systemic optimization of microalgae growth for bioremediation of swine wastewater and the potential for biofuel production. It's found that Scenedesmus dimorphus and Neochloris oleoabundans were unable to grow on the swine wastewater. The optimal culture conditions for Chlorella vulgaris and Chlamydomonas reinhardtii were found to be $\left(600 \mu \mathrm{m}^{-2} \mathrm{~s}^{-1}\right.$ and $\left.25^{\circ} \mathrm{C}\right)$ and $(300 \mu \mathrm{mol}$ $\mathrm{m}^{-2} \mathrm{~s}^{-1}$ and $20^{\circ} \mathrm{C}$ ), respectively. The growth kinetics was determined using Optical Density (OD) method and flow cytometry. Under the optimal culture conditions, the highest specific growth rates were found to be 1.336 day $^{-1}$ and 1.286 day $^{-1}$ for C. vulgaris and C. reinhardtii, respectively. Three microalgal strains of $C$. vulgaris, C. debaryana AT24 and C. reinhardtii were able to effectively treat swine wastewater, and the relationships between microalgae growth and the removal efficiency of nutrients were established. The final biomass yields and lipid contents were $1.25 \mathrm{~g} / \mathrm{L}$ and $15.2 \%$ (of the total cell dry weight), 0.86 $\mathrm{g} / \mathrm{L}$ and $19.7 \%$, and $0.73 \mathrm{~g} / \mathrm{L}$ and $21.7 \%$ for C. vulgaris, C. debaryana and $C$. reinhardtii, respectively. The potentials of using these microalgal biomass for biodiesel production were also addressed.

\section{Acknowledgment}

This publication was made possible by Grant Number NC.X-269-5-12-130-1 and NC.X2013-38821-21141 from the National Institute of Food and Agriculture. Its contents are solely the responsibility of the authors and do not necessarily represent the official views of the National Institute of Food and Agriculture.

\section{References}

1. Abdel-Raouf N, Al-Homaidan AA, Ibraheem IB (2012) Microalgae and wastewater treatment. Saudi J Biol Sci 19: 257-275.

2. Li Y, Horsman M, Wu N, Lan CQ, Dubois-Calero N (2008) Biofuels from microalgae. Biotechnol Prog 24: 815-820.

3. Zhang B (2013) New Golden Age of the Algal Technology. J Pet Environ Biotechnol 4:e120.

4. Chevalier P, Proulx D, Lessard P, Vincent WF, de la Noüe J (2000) Nitrogen and phosphorus removal by high latitude mat-forming cyanobacteria for potential use in tertiary wastewater treatment. J Appl Phycol 12: 105-112.

5. García J, Green BF, Lundquist T, Mujeriego R, Hernández-Mariné M, et al (2006) Long term diurnal variations in contaminant removal in high rate ponds treating urban wastewater. Bioresour Technol 97: 1709-1715.

6. Woertz I, Feffer A, Lundquist T, Nelson Y (2009) Algae Grown on Dairy and Municipal Wastewater for Simultaneous Nutrient Removal and Lipid Production for Biofuel Feedstock. J Environ Eng-ASCE 135: 1115-1122.

7. Borowitzka MA, Borowitzka LJ (1988) Micro-algal Biotechnology. Cambridge University Press United Kingdom.

8. Wahidin S Idris A, Shaleh SR (2013) The influence of light intensity and photoperiod on the growth and lipid content of microalgae Nannochloropsis sp. Bioresour Technol 129: 7-11.

9. Christie WW (1993) Preparation of lipid extracts from tissues. In Advances in Lipid Methodology-Two. Editor Christie WW, Oily Press, Dundee UK 195-213.

10. Indarti E, Majid MIA, Hashim R, Chong A (2005) Direct FAME synthesis for rapid total lipid analysis from fish oil and cod liver oil. Journal of Food Composition and Analysis 18: 161-170.

11. Zhang B, Carlson R, Srienc F (2006) Engineering the monomer composition of polyhydroxyalkanoates synthesized in Saccharomyces cerevisiae. Appl Environ Microbiol 72: 536-543.

12. Jung S, Rickert DA, Deak NA, Aldin ED, Recknor J, et al. (2003) Comparison of kjeldahl and dumas methods for determining protein contents of soybean products. J Am Oil Chem Soc 80: 1169-1173.

13. Zhang B, Wang Y (2013) Biomass Processing, Conversion and Biorefinery Nova Science Publishers, Inc., Hauppauge, NY.

14. Zhang B, Shahbazi A(2011) Recent Developments in Pretreatment Technologies for Production of Lignocellulosic Biofuels. J Pet Environ Biotechnol 2: 108.

15. Zhang B, Wang L, Shahbazi A, Diallo O, Whitmore A (2011) Dilute-sulfuric acid pretreatment of cattails for cellulose conversion. Bioresour Technol 102: 93089312. 